\title{
Removal of heavy metals from paint industry's wastewater using Leca as an available adsorbent
}

\author{
${ }^{1 *}$ M. Malakootian; ${ }^{2}$ J. Nouri; ${ }^{1}$ H. Hossaini \\ ${ }^{1}$ Department of Environmental Health, School of Public Health, Kerman University of Medical Sciences, Kerman, Iran \\ ${ }^{2}$ Department of Environmental Management, Graduate School of the Environment and Energy, Science and Research \\ Branch, IAU, Tehran, Iran \\ Received 4 December 2008; $\quad$ revised 18 January 2009; $\quad$ accepted 22 February 2009; $\quad$ available online 1 March 2009
}

\begin{abstract}
The ability of light expanded clay aggregate to remove lead and cadmium from paint industry's effluents was studied at different levels of adsorbent, contact time and $\mathrm{pH}$ in April 2008. For this purpose, lead and cadmium removal from paint industry effluents were studied in batch reactors. lead and cadmium measurements have been taken with non-flame atomic absorption techniques and test methods were adapted from $19^{\text {th. }}$ Ed. of standard methods for the examination of water and wastewater. In this study, different amounts of Leca (1, 2, 3, 4, 5, 6, 7, 8, 9 and $10 \mathrm{~g} / \mathrm{L})$ were investigated. The amount of adsorbed lead and cadmium exposure to Leca increased from 1.41 to $3 \mathrm{mg} / \mathrm{g}$ and 0.22 to 0.75 $\mathrm{mg} / \mathrm{g}$, respectively. The maximum removal efficiency for $\mathrm{Pb}$ was $93.75 \%$ at $\mathrm{pH}=7$ and exposure to $10 \mathrm{~g} / \mathrm{L}$ of Leca, while for cadmium, it was nearly $89.7 \%$ at the same condition. In this study, adsorption process of lead and cadmium was fitted with Freundlich adsorption isotherm $\left(\mathrm{R}_{\mathrm{Pb}}^{2}=0.97\right.$ and $\left.\mathrm{R}_{\mathrm{Cd}}^{2}=0.98\right)$. The sufficient contact time was deemed 1-2 $\mathrm{h}$ for lead and cadmium. According to the results, Leca is recommended as a low cost and available adsorbent to remove lead and cadmium from industrial wastewater.
\end{abstract}

Keywords: Lead, cadmium, adsorption, light expanded clay aggregate

\section{INTRODUCTION}

The release of heavy metals into the environment through industrial effluents is a major concern, worldwide and removal of such pollutants has been a great concern during last decades. $\mathrm{Pb}$ (II) and Cd (II) are particularly common heavy metals found in paint industries's wastewater. Heavy metals are not biodegradable and tend to be accumulated in organisms and cause numerous diseases and disorders (Ozer and Pirincci, 2006). Chronic exposure to high amount of lead and cadmium can result in various and considerable damages to systems of the body, including nervous and reproductive systems and kidneys. Moreover, high blood pressure, anemia, lead poisoning, coma and death can be considered among the most substantial consequences (PCS, 2001). Cadmium is an irritant to the respiratory tract and being exposure to this pollutant can lead to anemia, renal damage, osseous disease with the similar symptom as osteoporosis and Itai-Itai disease (Miyahara et al., 1980; SHMRC, 2003). The most widely used methods to

*Corresponding Author Email: m.malakootian@yahoo.com Tel: +098341 320 5074; Fax:+098341 3205105 remove heavy metals are chemical or electrochemical precipitation (Lai and Sheng, 2003; Mahvi, 2008). Adsorption process using activated carbon, widely used as an adsorbent, is among the most effective techniques for heavy metals removal from waste streams (Jusoh et al., 2007). In the last decades, there have been a great trend for using of low cost absorbents and different studies have demonstrated that natural agents have high removal capacity for divalent heavy metal ions (Ayyappana et al., 2005; Carrillo-Morales et al., 2001; Corami et al., 2008; Inglezakis et al., 2007; Naseem and Tahir, 2001). Different kinds of clays for removal of metal ions from aqueous solution have been studied and many factors effecting the absorbability of dissolved element, including chemical form of metal, $\mathrm{pH}$, contact time, metal concentrations, presence of competing adsorbents, amount of sorbent, temperature, particle size and others have been distinguished (Benjamin et al., 1982; Farrah and Pickering, 1977; Johnson, 1990; Orumwenese Faraday, 1996). Three major kinds of clays, including smectites (such as montmorillonite), kaolinite and micas 
have shown good metal removal efficiency. Montmorillonite has the highest cation exchange capacity and its current market price (about US\$ 0.04$0.12 / \mathrm{kg}$ ) is considered to be 20 times cheaper than that of activated carbon (Virtaa, 2002). In 1989, the removal efficiency of montmorillonite and kaolinite for lead and cadmium was compared and it was found that the adsorption capacity of $\mathrm{Pb}^{2+}$ and $\mathrm{Cd}^{2+}$ is greater on montmorillonite (Pb: 0.68, Cd: $0.72 \mathrm{mg} / \mathrm{g}$ ) than kaolinite (Pb: 0.12, Cd: 0.32 mg/g) (Babel and Agustino, 2003). Leca (light expanded clay aggregate) was selected as an adsorbent for removal of metal ions from paint industries effluents. Leca is an aggregate made of expanded clay produced in rotary kiln at the temperature around $1200{ }^{\circ} \mathrm{C}$. Thousands of small bubbles-like spaces will be produced during cooling process inside the clay and also a coarse surface is created. Leca aggregates are round in shape with coarse and disagreeable texture. The exterior color is brown and black with cellular structure inside. Its sponge-like and microscopic surface is considerable. Adsorption mechanism at clay surfaces is strictly related to the dual nature of the surface charge, permanent negative charge arises from non-stochiometric isomorphous substitution of cations of charge +4 and +3 with cations of charge +3 and +2 , respectively. But some articles discussed that an adsorption at the layer edges, involving more specific interactions with the surface, is more dependent on the $\mathrm{pH}$ and less dependent on ionic strength (Karbassi et al., 2008; Majone and Papini, 2006). Among the most remarkable specifications of Leca are lightness, insulation against thermal and sound, moisture impermeability, incompressibility under permanent and steady pressure, non-decomposition, fire resistance, $\mathrm{pH}$ of around 7 and freezing and melting resistance. The aggregates manufactured in Iran are presented in various sizes. Four usual gradations are $0-3 \mathrm{~mm}, 3-$ $10 \mathrm{~mm}, 10-20 \mathrm{~mm}$ and $0-25 \mathrm{~mm}$. Leca bulk dried density for different gradations is presented in Table 1. This study focuses on the removal of lead and cadmium from Binalood Paint Industry effluent (Kerman, Iran) by the usage of Saveh (a small city of IRAN) Leca as an adsorbent in April 2008.

\section{MATERIALS AND METHODS}

\section{Adsorbent preparation}

Proposed Leca was provided from Saveh Leca Industry at $3-10 \mathrm{~mm}$ size and special weight of $380 \mathrm{~kg} / \mathrm{m}^{3}$. The main characteristics of Leca are shown in Table 2.
Table 1: Density of Leca aggregates (LECA Co., 2006)

\begin{tabular}{lrrrl}
\hline Leca gradation $(\mathrm{mm})$ & $0-3$ & $3-10$ & $10-20$ & $0-25$ (mixed) \\
\hline Weight $\left(\mathrm{kg} / \mathrm{m}^{3}\right)$ & 560 & 380 & 330 & 380 \\
\hline
\end{tabular}

Table 2: Typical characteristics of Leca (LECA Co., 2006)

\begin{tabular}{lc}
\hline Elements/compounds & Value (wt. \%) \\
\hline $\mathrm{Al}_{2} \mathrm{O}_{3}$ & 16.57 \\
$\mathrm{SiO}_{2}$ & 66.06 \\
$\mathrm{CaO}$ & 2.46 \\
$\mathrm{Fe}_{2} \mathrm{O}_{3}$ & 7.1 \\
$\mathrm{~K}_{2} \mathrm{O}$ & 2.69 \\
$\mathrm{MgO}$ & 1.99 \\
$\mathrm{MnO}_{2}$ & 0.09 \\
$\mathrm{Na}_{2} \mathrm{O}$ & 0.69 \\
$\mathrm{P}_{2} \mathrm{O}_{5}$ & 0.21 \\
$\mathrm{TiO}_{2}$ & 0.78 \\
$\mathrm{LOI}^{*}$ & 1.36 \\
\hline
\end{tabular}

*Loss on ingnition

Different studies showed that particle size has significant effect on adsorption efficiency. Thus, smaller the particle size, higher the adsorption efficiency. Hence, the particle size decreases the surface area of the mineral due to increase of the incoming ion (Vassilis et al., 2007). Leca was crashed and sieved through a $30 \mathrm{~mm}$ mesh (remained on \# 20), then crashed materials were washed to remove fines and undesirable materials with dionized water several times and dried in oven at $110^{\circ} \mathrm{C}$ for $24 \mathrm{~h}$ to obtain constant weight (Chem and Wu, 2001).

\section{Characteristic and preparation of effluent samples}

Binalood Paint Industry with 70 tons/month paint productions has approximately a generation of 200 $\mathrm{m}^{3} /$ month wastewater. Since, high peak flow rate may be existed in industrial effluents and the concentration of metal ion may be different, therefore, samples were taken from industry equalization tank effluent $\mathrm{After} \mathrm{pH}$ and temperature measurements, samples were transferred to the laboratory in order to remove supernatant and undesirable suspended materials. Then, each sample was settled $1 \mathrm{~h}$ and filtered through a $0.45 \mu \mathrm{m}$ polycarbonate filter. For preservation of metals content, appropriate amount of $\mathrm{HCl}$ was added to each sample until $\mathrm{pH}$ decreased to less than 2 and these samples were kept at $4^{\circ} \mathrm{C}$. In order to determine raw wastewater characteristics, prepared samples were analyzed with nonflame atomic absorption techniques and test methods were adapted from $19^{\text {th }} \mathrm{Ed}$. of standard methods to examine water and wastewater (Eaton et al., 1998). In order to determine the effect of different conditions (contact time, $\mathrm{pH}$ and adsorbent amount) procedures were based on the other experiments carried out through similar studies 
(Malakootian et al., 2006; Nouri et al., 2008; Viraraghavan and Rao, 1991). Moreover, to determine the optimum contact time, $10 \mathrm{~g}$ of Leca was added to each jar containing $1000 \mathrm{~mL}$ sample with known metal concentration and $\mathrm{pH}$ and then shacked at $200 \mathrm{rpm}$ for $3 \mathrm{~h}$. Each $10 \mathrm{~min}$, sample was taken, until it reached to equilibrium level. For determining the effects of different $\mathrm{pH}$ on the adsorption rate, each prepared sample was influenced by appropriate amounts of $\mathrm{HCl}$ and $\mathrm{NaOH}$ solution and its $\mathrm{pH}$ adjusted to 3, 7 and 10 and optimum $\mathrm{pH}$ was determined for next steps. The adsorption isotherm models and equations in $25^{\circ} \mathrm{C} \pm 1$, $\mathrm{pH}=7$ and fixed concentration of $\mathrm{Pb}$ and $\mathrm{Cd}$ were used for different densities of adsorbent (1, 2, 3, 4, 5, 6, 7, 8, 9 and $10 \mathrm{~g} / \mathrm{L}$ ) and $3 \mathrm{~h}$ contact time. Then, samples were mixed with a mechanical mixer at $200 \mathrm{rpm}$ speed, centrifuged and filtered. $\mathrm{Pb}$ and $\mathrm{Cd}$ measurements were done for the effluent and the settled sediments. Sediments were rinsed and filtered with deionized water and after measurement they were used in calculations. To control any leaching interference during the test period, a sample was prepared adding Leca to 1000 cc of deionized water as a blank sample. This study conducted research in 1 to $3 \mathrm{~h}$ contact time.

\section{RESULTS AND DISCUSSION}

Table 3 shows the average of ten raw wastewater samples before $1 \mathrm{~h}$ settling and after transferring to the laboratory. The results showed that $\mathrm{Pb}$ and $\mathrm{Cd}$ concentrations were 5.6 and $1.8 \mathrm{mg} / \mathrm{L}$, respectively . According to results, the concentrations of heavy metals in wastewater used in agricultural irrigation are more than relevant $\mathrm{MCL}_{\mathrm{s}}$ (5 and $0.01 \mathrm{mg} / \mathrm{L}$ ) and is propounded as the most important environmental problem concerning this wastewater and required specific care (Ayers and Westcot, 1994).

\section{Determination of optimum contact time}

Fig. 1 shows that adsorption of $\mathrm{Pb}$ and $\mathrm{Cd}$ reached equilibrium in the range of 60 to $90 \mathrm{~min}$ and 110 to 130 min of contact time, respectively while removal efficiency for $\mathrm{Pb}$ and $\mathrm{Cd}$ at these contact times was $93.75 \%$ and $89.7 \%$, respectively. Fig. 1, obviously shows that uptake of $\mathrm{Cd}$ and $\mathrm{Pb}$ by Leca was rapid within the first $20 \mathrm{~min}$ of contact time. The removal rate of $\mathrm{Cd}$ and $\mathrm{Pb}$ gradually decreased with increase in contact time. Initially, the rate of $\mathrm{Cd}$ and $\mathrm{Pb}$ was higher because all sites on Leca were vacant and concentration was high, but decrease of sorption sites reduced the uptake rate. As it was shown in the same Fig, desorption will be occurred after saturation. Therefore, considering technical and economical aspects, $1-2 \mathrm{~h}$ contact time is recommended for lead and cadmium removal from wastewater by Leca adsorption. Results of this study are in entirely accordance to the results of Inglezakis et al. (2007) and Malakootian et al. (2006). Inglezakis et

Table 3: Raw wastewater characteristics of Binalood Paint Industries

\begin{tabular}{llcr}
\hline Parameters & Unit & Mean & SD \\
\hline $\mathrm{pH}$ & $\mathrm{pH}$ unit & 5.7 & 0.96 \\
$\mathrm{~Pb}$ & $\mathrm{mg} / \mathrm{L}$ & 5.6 & 1 \\
$\mathrm{Cd}$ & $\mathrm{mg} / \mathrm{L}$ & 1.8 & 0.9 \\
\hline
\end{tabular}

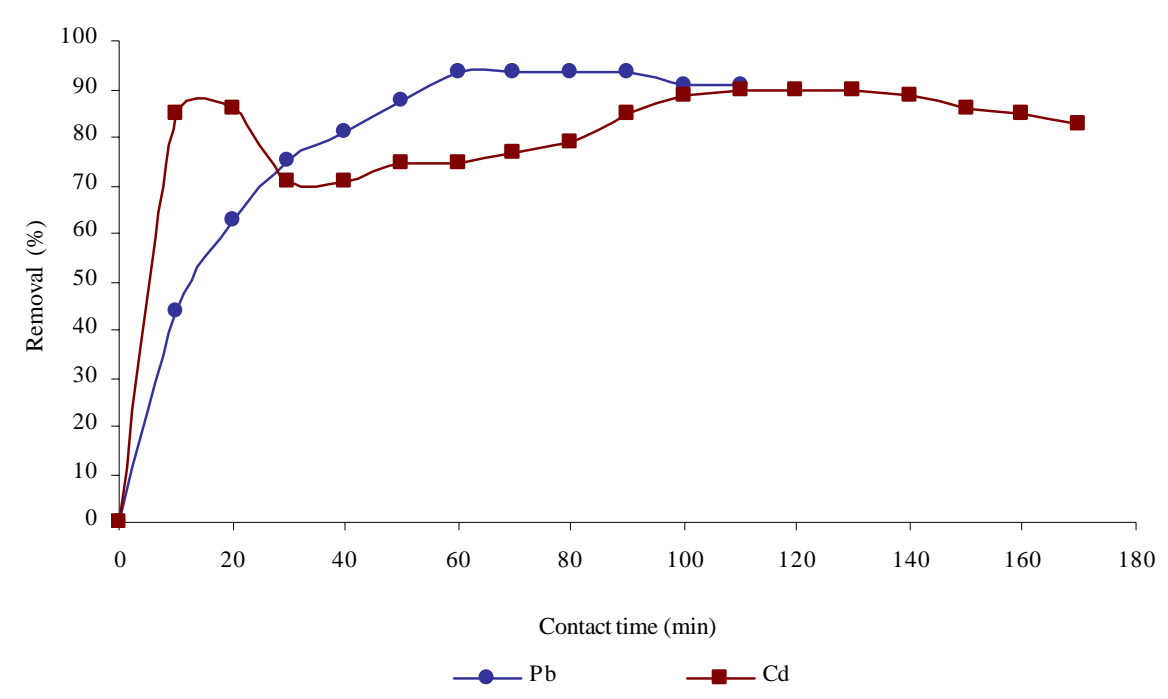

Fig. 1: Optimum contact time of $\mathrm{Pb}$ and $\mathrm{Cd}$ adsorption on Leca, $\mathrm{T}=25^{\circ} \mathrm{C}, \mathrm{pH}=7$ 
Heavy metals removal from paint industries wastewater

Table 4: Comparing the performance of different supports

\begin{tabular}{|c|c|c|c|c|c|c|}
\hline \multirow{2}{*}{\multicolumn{2}{|c|}{ Sorbent support }} & \multicolumn{2}{|c|}{$\mathrm{Q}$} & \multicolumn{2}{|c|}{ Removal (\%) } & \multirow{2}{*}{ Reference } \\
\hline & & $\mathrm{Cd}$ & $\mathrm{Pb}$ & $\mathrm{Cd}$ & $\mathrm{Pb}$ & \\
\hline Leca & & 0.22 to $0.75 \mathrm{mg} / \mathrm{g}$ & 1.41 to $3 \mathrm{mg} / \mathrm{g}$ & 89.7 & 93.75 & Current results \\
\hline Fly ash & & - & - & 93 & - & Viraraghavan and Rao, 1991 \\
\hline \multirow{2}{*}{ Buomass } & Crab shell & - & $19.83 \pm 0.29 \mathrm{mg} / \mathrm{g}$ & - & - & \multirow{2}{*}{ Dahiya et al., 2008} \\
\hline & Arca shell & - & $18.33 \pm 0.44 \mathrm{mg} / \mathrm{g}$ & - & - & \\
\hline Wood ash & & $0.05-0.019$ & - & 98 & - & Malakootian et al., 2006 \\
\hline \multicolumn{2}{|l|}{ Wood ash } & - & - & - & 96.1 & Malakootian et al., 2008 \\
\hline \multicolumn{2}{|c|}{ Hydroxiapatite } & $0.058-1.681 \mathrm{mmol} / \mathrm{g}$ & - & 83 & - & Corami et al., 2008 \\
\hline \multicolumn{2}{|c|}{ Clinoptilolite } & $2.40 \mathrm{mg} / \mathrm{g}$ & $1.60 \mathrm{mg} / \mathrm{g}$ & - & - & Zamzow et al., 1990 \\
\hline \multicolumn{2}{|c|}{ Montmorillonite } & $0.72 \mathrm{mg} / \mathrm{g}$ & $0.68 \mathrm{mg} / \mathrm{g}$ & - & - & Srivastava et al., 1989 \\
\hline
\end{tabular}
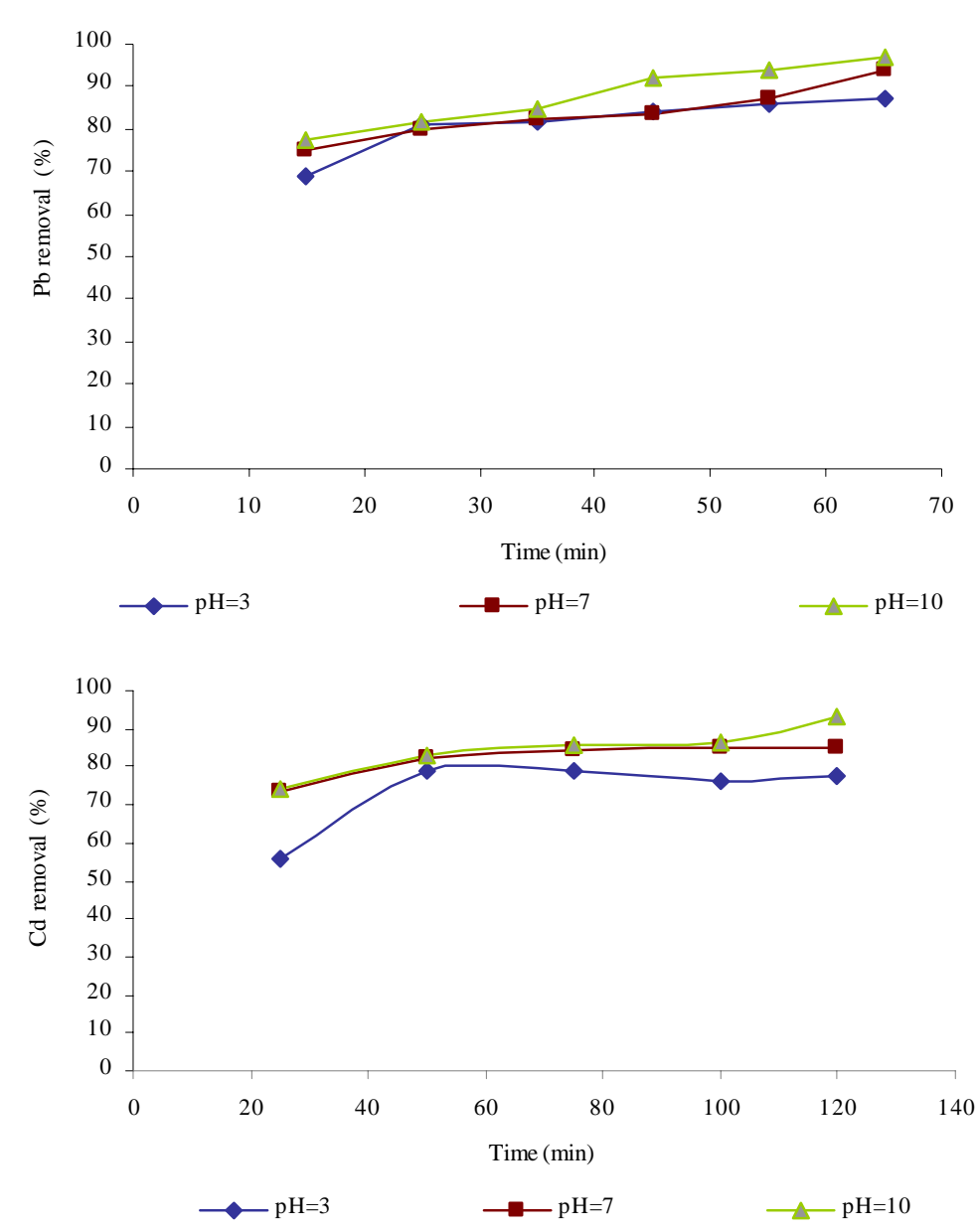

Fig. 2: Effect of $\mathrm{pH}$ for $\mathrm{Cd}$ and $\mathrm{Pb}$ adsorption on Leca

al. (2007) showed that $120 \mathrm{~min}$ is a sufficient time for $\mathrm{Pb}$ adsorption on Bentonite and Clinoptilolite. The removal of $\mathrm{Pb}$ (II) using Bentonite reached $100 \%$ and $55 \%$ for Clinoptilolite at ambient temperature and mild agitation (100 rpm) (Vassilis et al., 2007). Pb removal efficiency was lower than last results obtained on wood ash (96.1 \%) due to higher amount of applied wood ash
(Malakootian et al., 2008). Weakly sorption of cadmium attributed with the fact that Cadmium adsorbs rather weakly on organic matter, silicate clay and oxides (Mcbride, 1994). Leca showed higher Cd removal efficiency than other studied minerals material like hydroxiapatite (Cd removal efficiency $=83 \%$ ) and it showed lower efficiency than fly ash (Corami et al., 

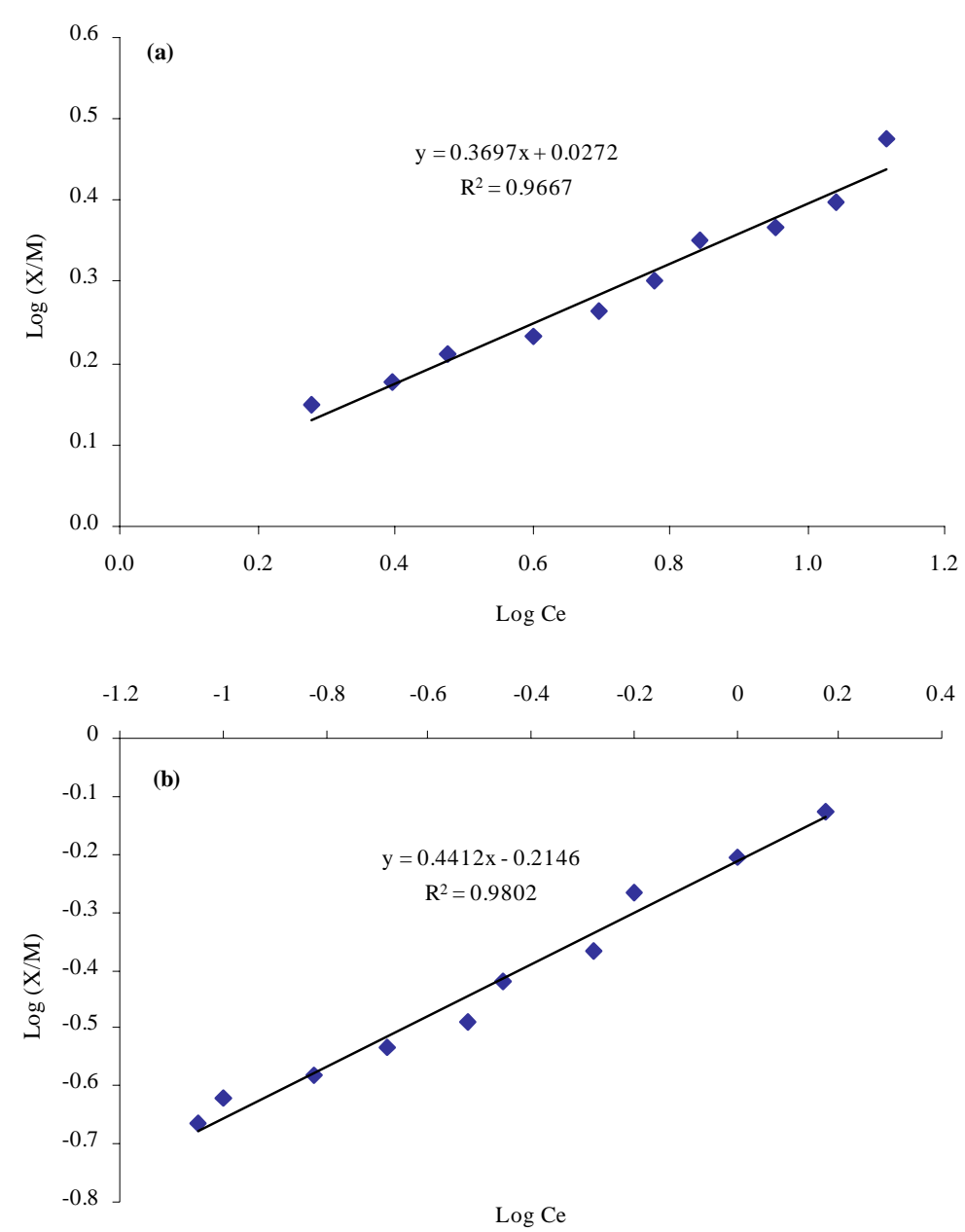

Fig. 3: Freundlich isotherm for metal removal by Leca, $\mathrm{pH}=7, \mathrm{~T}=25^{\circ} \mathrm{C}$ (a: $\mathrm{Pb}$; b: $\mathrm{Cd}$ )

Table 5: Freundlich and Langmuir model parameters

\begin{tabular}{lcc}
\hline Freundlich model & Pb adsorption on Leca & Cd adsorption on Leca \\
\hline $\mathrm{K}_{\mathrm{F}}$ & 1.064 & 0.61 \\
$1 / \mathrm{n}$ & 0.369 & 0.44 \\
$\mathrm{R}^{2}$ & 0.97 & 0.98 \\
& & \\
Langmuir model & & Cd adsorption on Leca \\
$\mathrm{q}_{\mathrm{m}}$ & Pb adsorption on Leca & 0.91 \\
$\mathrm{~K}_{\mathrm{L}}$ & 3.53 & 2.4 \\
$\mathrm{R}^{2}$ & 0.25 & 0.949 \\
\hline
\end{tabular}

2008; Viraraghavan and Rao, 1991) as a result of fly ash small size classification. Leca in comparaison with wood ash showed better removal efficiency regarding $\mathrm{Pb}$ (Malakootian et al., 2008). Table 4 compares the performance of this support compared to others.

\section{Effect of Leca quantity and $\mathrm{pH}$ (Fig. 2)}

Study of different densities of Leca showed that the amount of adsorbent has a great role in adsorption of $\mathrm{Cd}$ and $\mathrm{Pb}$. In this study, different amounts of Leca $(1,2,3,4,5,6,7,8,9$ and $10 \mathrm{~g} / \mathrm{L})$ were sampled and the obtained results showed that increasing the amount 

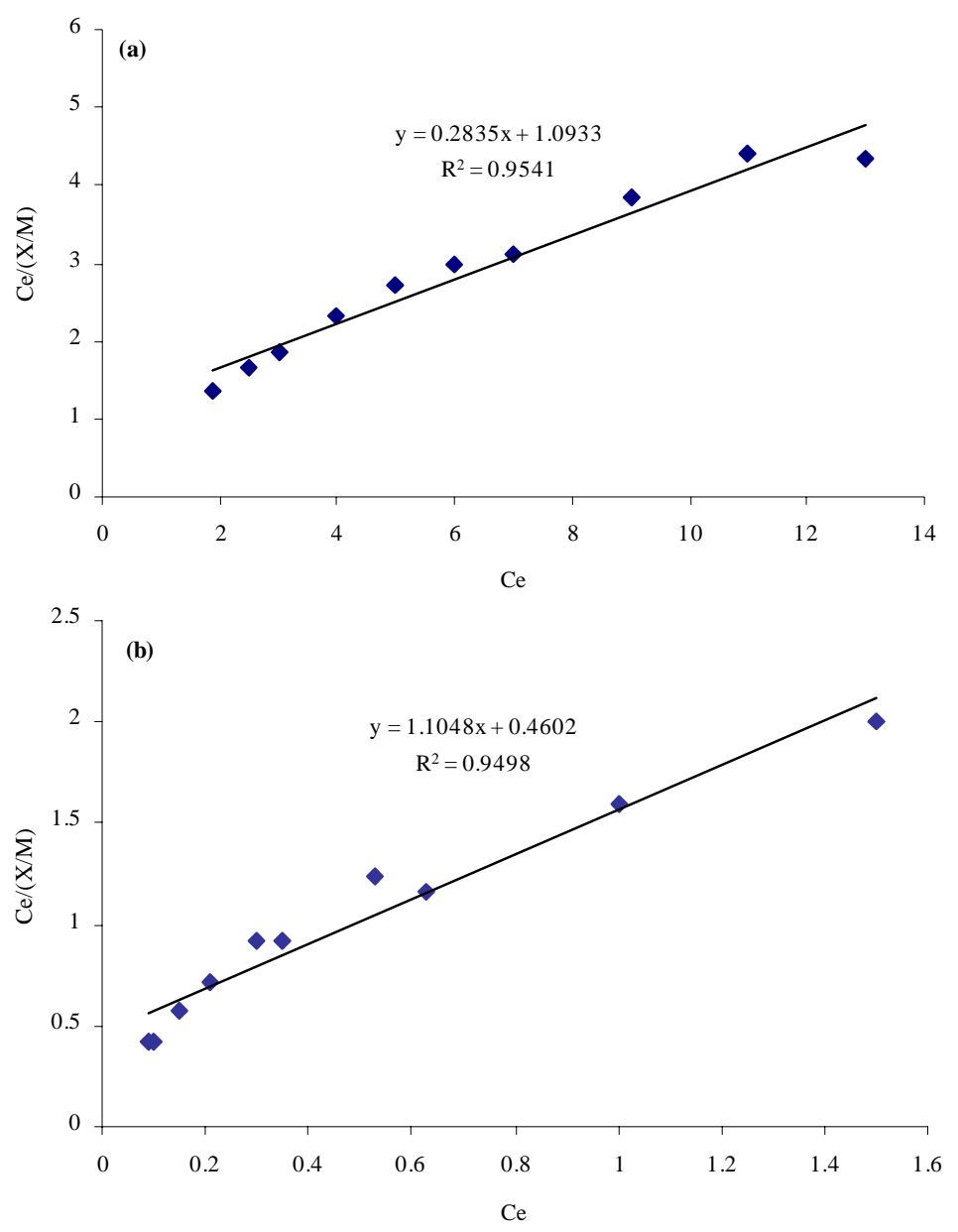

Fig. 4: Langmuir isotherm for metal removal by Leca, $\mathrm{pH}=7, \mathrm{~T}=25^{\circ} \mathrm{C}$ (a: $\mathrm{Pb}$; b: $\mathrm{Cd}$ )

of sorbent, the sorption sites were increased, but the residual metal concentration was obviously decreased (regarding high sorption) and limited the sorption efficiency. The results reveal that the unit adsorption (q) was high at low dose and reduced at high dose. The amount of adsorbed $\mathrm{Pb}$ (II) and Cd (II) increased from 1.41 to $3 \mathrm{mg} / \mathrm{g}$ and 0.22 to $0.75 \mathrm{mg} / \mathrm{g}$, respectively. In this study, by increasing the purposed metal ion by two times of their MCLs for agricultural irrigation usage, $10 \mathrm{~g} / \mathrm{L}$ Leca was selected. In order to investigate the effect of $\mathrm{pH}$, the same amount of Leca in different $\mathrm{PH}_{\mathrm{s}}$ (3, 7 and 10) was studied. The results showed that maximum $\mathrm{Pb}$ adsorption was $96.8 \%$ in $10 \mathrm{~g} / \mathrm{L}$ Leca and $\mathrm{pH}=10$ and maximum Cd adsorption was approximately $89.7 \%$ at the same condition. Investigation the effects of $\mathrm{pH}$ on the adsorption rate of $\mathrm{Cd}$ and $\mathrm{Pb}$ by Leca was illustrated in Fig. 2 and as it is clear, adsorption is done at various ranges of $\mathrm{pH}$, from 3 to 10 and $\mathrm{pH}$ variations have relatively great effect on the adsorption rate. There was a gradual increase in adsorption rate related to increasing $\mathrm{pH}$ from 3 to 10 due to this fact that alkaline condition on sorbent produce more negative charge on the surface (Viraraghavan and Rao, 1991). The maximum removal efficiency of $\mathrm{Pb}$ and $\mathrm{Cd}$ was at alkaline condition $(\mathrm{pH}=10)$ and these results were in accordance with the results of McBride (1994). Considering these results and the limitations concerning the discharge of acidic and alkaline effluents to the environment, neutral $\mathrm{pH}$ is logical and acceptable in the removal process.

\section{Adsorption model (Figs. 3 and 4)}

For modeling of the heavy metals adsorption from wastewater, two models (Langmuir and Freundlich) were used. These models are useful in the full scale applications. As Figs. 3 and 4 show, the adsorption of 
$\mathrm{Pb}$ and $\mathrm{Cd}$ by Freundlich isotherm is better explained. The value of Freundlich and Langmuir constant was presented in Table 5. It will be noted that the value of $1 / n$ was between 0 and 1indicating that the sorption of metal ions into Leca was favorable under the mentioned conditions.

Original form

Linearized form

1. Langmuir model

$$
q=\frac{q_{m} \cdot K_{L} \cdot C}{1+K_{L} \cdot C}
$$$$
\frac{C}{q}=\frac{1}{K_{L} \cdot q_{m}}+\frac{1}{q_{m}} \cdot C
$$

2. Freundlich model

$$
q=K_{F} \cdot C^{\frac{1}{n}} \quad \log q=\log K_{F}+\frac{1}{n} \cdot \log C
$$

Where,

q: The amount of metal ions adsorbed per specific amount of adsorbent (mg/g)

$\mathrm{C}$ : Equilibrium concentration $(\mathrm{mg} / \mathrm{L}$ or $\mathrm{mmol} / \mathrm{L}$ )

$\mathrm{q}_{\mathrm{m}}$ : The amount of metal ions required to form a monolayer (mg/g)

$\mathrm{K}_{\mathrm{L}}$ : Langmuir equilibrium constant

$\left(\mathrm{K}_{\mathrm{F}}\right)$ and $(1 / \mathrm{n})$ are indicative isotherm parameters of sorption capacity and intensity, respectively. As a consequence, the Freundlich isotherms for Pb removal by Leca can be represented by the following empirical formula:

$\mathrm{q}=1.064 x^{0.369}$

and Cd removal by Leca can be represented as:

$\mathrm{q}=0.61 x^{0.44}$

Results showed that Leca as an available, natural and low cost material can be considered as an alternative in the removal of heavy metals from this type of wastewater and similar ones.

\section{ACKNOWLEDGEMENTS}

The authors are grateful to Binalood Paint Industry directorate for their cooperation and also to Environmental Health Research Commission of Kerman university of Medical Sciences for project approval.

\section{REFERENCES}

Ayyappan, R.; Carmalin Sophia, A.; Swaminathan K.; Sandhya, S., (2005). Removal of Pb (II) from aqueous solution using carbon derived from agricultural wastes. Proc. Biochem., 40 (3-4),1293-1299 (7 pages).
Ayers, R. S.; Westcot, M., (1994). Water quality for agriculture, Food and Agriculture Organization of the United Nations Rome, FAO. Rome, Italy.

Babel, S.; Agustiono, K. T., (2003). Low-cost adsorbents for heavy metals uptake from contaminated water: A review. J. Hazard. Mater., 97 (1-3), 219-243 (25 pages).

Benjamin, M. M.; Hayes, K. F.; Leckie; J. O., (1982). Removal of toxic metals from power generation waste streams by adsorption and co-percipitation. Water Pollut. Control Fed., 54 (11), 1472-1481 (10 pages).

Carrillo-Morales, G.; Dávila-Jiménez, M. M.; Elizalde-González, M. P.; Peláez-Cid, A. A., (2001). Removal of metal ions from aqueous solution by adsorption on the natural adsorbent ACMM2. J. Chromatogr., A., 938 (1-2), 237-242 (6 pages). Chem, J. M.; Wu, C. Y., (2001). Desorption of dye from activated carbon beds: Effects of temperature, $\mathrm{pH}$ and alcohol. Water Res., 35 (17), 4159-4165 (7 pages).

Corami, A.; Mignardi, S.; Ferrini, V., (2008). Cadmium removal from single- and multi-metal $(\mathrm{Cd}+\mathrm{Pb}+\mathrm{Zn}+\mathrm{Cu})$ solution by sorption on hyroxyapatite. J. Coll. Interf. Sci., 317 (2), 402-408 (7 pages).

Dahiya, S.; Tripathi, R. M.; Hegde, A. G., (2008). Biosorption of lead and copper from aqueous solutions by pre-treated crab and arca shell biomass. Bioresour. Tech., 99 (1), 179187 (8 pages).

Eaton, A.; Closceril, L.; Greanberg, A., (1998). Standard methods for the examination of water and wastewater. APHA, AWWA, WEF. USA. 3-54, 53-55 (3 pages).

Farrah, H.; Pickering, W. F., (1977). The sorption of lead and cadmium species by clay minerals. Aust. J. Chem., 30 (7), 1417-1422 (6 pages).

Inglezakis, V.; Stylianou, M. A.; Gkantzou, D.; Loizidou, M. D., (2007). Removal of $\mathrm{Pb}(\mathrm{II})$ from aqueous solutions by using clinoptilolite and bentonite as adsorbents. Desalination, 210 (1-3), 248-256 (9 pages).

Johnson, B. B., (1990). Effect of pH, temperature and concentration on the adsorption of cadmium on Goethite. Environ. Sci. Tech., 24 (1), 112-118 (6 pages).

Jusoh, A.; Su, S. L.; Nora'aini, A.; Noor, M. J. M. M., (2007). A simulation study of the removal efficiency of granular activated carbon on cadmium and lead. Desalination, 206 (1-3), 9-16 (8 pages).

Karbassi, A. R., Nouri, J., Mehrdadi, N., Ayaz, G. O., (2008). Flocculation of heavy metals during mixing of freshwater with Caspian Sea water. Environ. Geo., 53 (8), 1811-1816 (6 pages).

Lai, C. L.; Sheng, H. L., (2003). Electrocoagulation of chemical mechanical polishing (CMP) wastewater from semiconductor fabrication. Chem. Eng., 95 (1-3), $205-211$ (7 pages).

Leca Co., (2006). What is Leca? Leca co Iran. Available from: http://www.Leca.ir/index.

Mahvi, A. H., (2008). Application of agricultural fibers in pollution removal from aqueous solution. Int. J. Environ. Sci. Tech., 5 (2), 275-285 (11 pages).

Majone, M.; Papini, M. P., (2006). Encyclopedia of surface and colloid science, $2^{\text {nd. }}$ Ed., Taylor and Francis Group. New York.

Malakootian, M.; Yaghmaeian, K.; Malakootian, M., (2006). Wood ash effectiveness in cadmium removal from paint industrial effluent. Pakistan J. Bio. Sci., 9 (2), 248-252 (5 pages). 
Malakootian, M.; Almasi, A.; Hossaini, H., (2008). Pb and Co removal from paint industries effluent using wood ash. Int. J. Environ. Sci. Tech., 5 (2), 187-192 (5 pages).

Mcbride, M. B., (1994). Environmental Chemistry of Soils. Oxford University Press, Inc., New York.

Miyahara, T.; Miyakoshi, M.; Saito, Y.; Kozuka, H.,(1980). Influence of poisonous metals on bone metabolism: III. the effect of cadmium on bone resorption in tissue culture. Toxic. Appl. Pharma., 55 (3), 477-483 (7 pages).

Naseem, R.; Tahir, S. S., (2001). Removal of Pb (II) from aqueous/ acidic solutions by using bentonite as an adsorbent. Wat. Res., 35 (16), 3982-3986 (5 pages).

Nouri, J.; Mahvi, A. H.; Jahed, G. R.; Babaei, A. A., (2008). Regional distribution pattern of groundwater heavy metals resulting from agricultural activities. Environ. Geo., 55 (6), 1337-1343 ( 7 pages).

Orumwense Faraday, F. O., (1996). Removal of lead from water by adsorption on a kaolinitic clay. J. Chem. Tech. Biotech., 65 (4), 365-369 (5 pages).

Ozer, A.; Pirincci, H. B., (2006). The adsorption of Cd (II) ions on sulphuric acid-treated wheat bran. J. Hazard. Mater., 137 (2), 849-855 (7 pages).

PCS, (2001), Water-related diseases, reviewed by staff and experts in the Programme of Chemical Safety, Geneva.
SHMRC, (2003). Heavy metal handbook a guide for healthcare practitioners, Science Subcommittee of the Heavy Metals Remediation Committee of the Vashon-Maury Island Community Council, Available from: http://www.vmicc.org/ comm_metals.html.

Srivastava, S. K.; Tyagi, R.; Pant, N.; Pal, N., (1989). Studies on the removal of some toxic metal ions. Part II removal of lead and cadmium by montmorillonite and kaolinite. Environ. Tech., 10 (3), 275-282 (8 pages).

Vassilis, J. I.; Marinos, A. S.; Despoina, G.; Maria, D. L., (2007). Removal of $\mathrm{Pb}$ (II) from aqueous solutions by using clinoptilolite and bentonite as adsorbents. Desalination 210, 248-256 (9 pages).

Viraraghavan, T.; Rao, G. A. K., (1991). Adsorption of cadmium and chromium from wastewater by fly ash. Environ. Sci. Health A., 26 (5), 721-753 (33 pages).

Virta, R., (2002). USGS Minerals Information. US geological Survey Mineral Commodity Summary.

Zamzow, M.; Eichbaum, B.; Sandgren, K.; Shanks, D., (1990). Removal of heavy methals and other cations from wastewater using zeolites, Separ. Sci. Tech., 25 (13-15), 1555-1569 (15 pages).

\section{AUTHOR (S) BIOSKETCHES}

Malakootian, M., Ph. D., Associate professor, Department of Environmental Health, School of Public Health, Kerman University of Medical Sciences, Kerman, Iran. Email: m.malakootian@yahoo.com.

Nouri, J., Ph.D., Full professor, Department of Environmental Management, Graduate School of the Environment and Energy, Science and Research Branch, Islamic Azad University, also as adjunct professor of the Department of Environmental Health Engineering, School of Public Health, Tehran University of Medical Sciences, Tehran, Iran. Email: nourijafar@gmail.com

Hossaini, H., Postgraduate student, Environmental Health Engineering, Post Graduated Programme, Department of Environmental Health, School of Public Health, Kerman University of Medical Sciences, Kerman, Iran. Email: hhiwa_kmu@yahoo.com

This article should be referenced as follows:

Malakootian, M.; Nouri, J.; Hossaini, H., (2009). Removal of heavy metals from paint industries wastewater using Leca as an available adsorbent. Int. J. Environ. Sci. Tech., 6 (2), 183-190. 